\title{
RENCANA BISNIS PENGOLAHAN DAN PENJUALAN SAMBEL NY. GUNAWAN
}

\author{
Linda Martina Gunawan \\ Program Studi Magister Manajemen Universitas Tarumanagara \\ liemlindagunawan@gmail.com \\ Mukti Rahardjo \\ Program Studi Magister Manajemen Universitas Tarumanagara
}

Masuk : 06-06-2020, revisi : 03-07-2020 diterima untuk diterbitkan : 06-07-2020

\begin{abstract}
The slow growth of the Indonesia economic condition and the downward trend of culinary in Indonesia should not become a barrier to enter the Indonesia culinary industry. This business plan will provide the information needed to assist the investors in evaluating aspects of business feasibility and also provide guidelines and strategies for all enterpreneurs who wants to enter and start business in Indonesia culinary industry. This business aim to become a pioneer in Indonesia culinary industry by providing custom products and digital marketing system for Indonesia culinary industry in attempt gain competitive adventage. Based on the result of the business plan feasibility study, this business has obtained good result with NPV value of IDR 1,615,554,130 which is greater that zero. With an IRR value of 19,32\%, it shows that the investment to this business can exceed the rate of interest in Indonesia bank generally. By having payback period in less than 4 years, this business is feasible to run.
\end{abstract}

Keywords: Business Plan, Indonesia Culinary Industry, Feasibility Study

Abstrak: Lambatnya pertumbuhan kondisi ekonomi Indonesia dan tren penurunan kuliner di Indonesia seharusnya tidak menjadi hambatan untuk memasuki industri kuliner Indonesia. Rencana bisnis ini akan memberikan informasi yang diperlukan untuk membantu investor dalam mengevaluasi aspek kelayakan bisnis dan juga memberikan pedoman dan strategi untuk semua pengusaha yang ingin masuk dan memulai bisnis di industri kuliner Indonesia. Bisnis ini bertujuan untuk menjadi pelopor dalam industri kuliner Indonesia dengan menyediakan produk khusus dan sistem pemasaran digital untuk industri kuliner Indonesia dalam upaya mendapatkan petualangan kompetitif. Berdasarkan hasil studi kelayakan rencana bisnis, bisnis ini telah memperoleh hasil yang baik dengan nilai NPV Rp. 1.615.554.130, - yang lebih besar dari nol. Dengan nilai IRR 19,32\%, itu menunjukkan bahwa investasi untuk bisnis ini dapat melebihi tingkat bunga di bank Indonesia pada umumnya. Dengan memiliki periode pengembalian dalam waktu kurang dari 4 tahun, bisnis ini layak untuk dijalankan.

Kata kunci: Rencana Bisnis, Industri Kuliner Indonesia, Studi Kelayakan

\section{PENDAHULUAN}

Industri kuliner di Indonesia, merupakan sektor yang strategis bagi perkembangan ekonomi di Indonesia. Kuliner bukan lagi produk konsumsi untuk memenuhi kebutuhan biologis manusia semesta, saat ini sudah menjadi sebuah trend atau gaya hidup baru dikalangan masyarakat. Pertumbuhan kuliner sangat berkembang pesat, semakin diminati oleh masyarakat, semakin kreatif, dan inovatif. Semakin banyak bisnis kuliner yang baru dimulai dari hasil kreatifitas dan umumnya pebisnis tergolong usia remaja beranjak dewasa. Namun tidak sedikit pula pelaku usaha kuliner yang gulung tikar alias bangkrut, karena strategi pemasaran yang digunakan kurang tepat dan kualitas pelayanan yang kurang optimal. Artinya keberhasilan sebuah bisnis kuliner dalam memenangkan persaingan ditentukan oleh strategi 
bersaing dari perusahaan itu sendiri. Strategi pemasaran juga merupakan salah satu poin penting dalam menjalankan suatu bisnis dengan menjalin hubungan baik dengan konsumen.

Semakin banyaknya pembisnis kuliner baru bermunculan, hal ini juga bisa dikatakan sebagai ancaman bagi pembisnis kuliner lama. Karena pembisnis kuliner baru saat ini lebih pintar dan lebih kreatif untuk memasarkan produknya dengan menggunakan media sosial tersebut. Oleh karena itu sekarang beberapa pemain lama yang bergerak di bisnis kuliner ini mulai kalah saing dengan yang baru tetapi beberapa mulai mengikuti dan beralih menggunakan media sosial khususnya Instagram untuk membantu memasarkan bisnisnya. Sesuai dengan saran yang diberikan oleh peneliti sebelumnya dan info yang ada dilapangan, maka perlu dilakukan studi lanjutan mengenai strategi pemasaran menggunakan media social secara lebih mendalam dan untuk mengetahui lebih dalam lagi mengapa pembisnis kuliner lama mulai beralih dengan menggunakan media sosial sebagai media pemasaran, padahal keberhasilan dengan menggunakan media sosial tersebut belum pasti dampaknya.

Perusahaan kuliner Sambel Ny. Gunawan yang akan dibangun ini bergerak dibidang kuliner makanan dalam bentuk sambel yang dikemas dalam botol yang merupakan produk yang langsung dapat dikonsumsi oleh konsumen. Perusahaan memilih untuk menyajikan sambel dalam bentuk botol dengan tujuan dapat memenuhi kebutuhan konsumen dimanapun konsumen berada, dengan kemasan botol ini tentukan akan lebih mudah dan praktis untuk dibawa kemana-mana dan dinikmati dimana saja. Promosi yang akan digunakan sebagian besar berbasis internet melalui jejaring social khususnya Instagram dengan bekerja sama dengan beberapa orang yang sudah ahli dalam melakukan iklan atau endorse melalui media Instagram maupun Youtube. Hal ini dilakukan dengan cara membuat video dengan konten seseorang yang di endorse sedang menikmati citrarasa dari Sambel Ny. Gunawan untuk menarik konsumen yang menonton video tergiur untuk ikut serta merasakan citra rasa pada Sambel Ny. Gunawan. Dengan begitu maka penulis bertujuan menarik konsumen melalui jejaring social terlebih dahulu sekaligus melakukan branding. Kegiatan untuk branding produk ini dilakukan dengan tujuan akan dibuka stand atau kios fisik untuk penjualan Sambel Ny. Gunawan. Sejauh ini, penjualan Sambel Ny. Gunawan akan dilakukan secara online melalui media Instagram. Namun kedepannya akan dilakukan perkembangan dengan menjual melalui Tokopedia, Shopee, Lazada, dan lainnya. Selain itu juga akan dibuka stand atu kios fisik dibeberapa mall dengan tujuan mendongkrak penjualan Sambel Ny. Gunawan. Dengan memberikan rasa praktis untuk menikmati sambel seperti yang ditawakan oleh Sambel Ny. Gunawan, penulis mempercayai bahwa rencana bisnis ini akan berhasil dilakukan dengan memiliki nilai jual yang tinggi dari segi citrarasa dan kemasan yang praktis dapat dibawa kemana saja, akan dapat bersaing dengan produk sejenisnya dalam pasar kuliner.

\section{Masalah}

Terus meningkatnya peminat kuliner akan produk kuliner di Indonesia membuat persaingan di pasar kuliner menjadi begitu ketat dengan banyaknya pebisnis kuliner baru yang semakin kreatif terhadap produk yang ditawarkan. Dari sisi lain para pebisnis baru ini memiliki cara sendiri untuk memasarkan produknya yakni kearah digital melalui jejaring sosial. Beberapa pemain lama yang tidak mengikuti perkembangan zaman ini akan tertinggal. Saat ini memiliki brand yang sudah dikenal masyarakat tidaklah cukup karena dalam bisnis kuliner kegiatan pemasaran terhadap brand agar tetap diingat masyarakat itu merupakan hal yang tak kalah penting, selain itu inovasi produk juga merupakan strategi yang penting bagi kelangsungan suatu perusahaan kuliner agar tak tertinggal dengan masa dan zaman. Selain itu tentunya masih banyak strategi dalam suatu perusahaan yang perlu dilakukan untuk kelangsungan hidup suatu perusahaan. Diharapkan melalui penelitian ini dapat memberikan kemudahan kepada para pebisnis baru seperti Sambel Ny. Gunawan untuk dapat terus menjaga kelangsungan hidup dan dapat bersaing dalam pasar kuliner yang ketat. 


\section{Tujuan}

Tujuan dari penulisan business plan ini adalah melakukan perancangan bisnis mengenai permasalahan yang terjadi dan berusaha memaparkan peluang dan solusi-solusi yang disajikan dari permasalahan-permasalahan tersebut, sehingga diharapkan dapat menarik para investor untuk berinvestasi dalam industri kuliner Indonesia. Selain itu juga diharapkan dengan perancangan bisnis ini, dapat menciptakan perusahaan yang lebih kompetitif dan memiliki daya saing serta memberikan nilai yang lebih kepada para penikmat kuliner, baik secara nasional maupun internasional

\section{PEMBAHASAN}

\section{Analisis Segmenting, Targeting, dan Positioning (STP)}

Strategi STP pada dasarnya digunakan untuk memposisikan suatu merek dalam benak konsumen sedemikian rupa sehingga merek tersebut memiliki keunggulan kompetitif yang berkesinambungan. Diperlukannya proses STP (segmenting, targeting, positioning) agar dapat mempersempit pasar yang ada sehingga dapat lebih focus dengan target pasar yang dituju dan membangun hubungan yang baik dengan konsumen yang benar. Segmentasi pasar dilakukan berdasarkan faktor-faktor seperti usia, lokasi, dan juga pendapatan seseorang. Dengan begitu, maka profil target pasar akan ditentukan berdasarkan 3 variabel tersebutm dimana pasar yang dituju berada pada segmen pasar yang berusia dibawah atau diatas 25 tahun, didalam atau diluar area Jakarta, dan kalangan dengan kelas sosial menengah kebawah atau menengah keatas.

\section{Analisis SWOT}

SWOT adalah suatu bentuk analisis di dalam manajemen perusahaan atau di dalam organisasi yang secara sistematis dapat membantu dalam usaha penyusunan suatu rencana yang matang untuk mencapai tujuan, baik itu tujuan jangka pendek maupun tujuan jangka panjang. SWOT digunakan untuk menilai kekuatan-kekuatan dan kelemahan-kelemahan dari sumber-sumber daya yang dimiliki perusahaan dan kesempatan-kesempatan eksternal dan tantangan-tantangan yang dihadapi.

\section{Strength}

Strength (kekuatan) adalah sesuatu hal yang sangat baik dan sangat dikuasai oleh perusahaan atau juga sebuah atribut yang dapat meningkatkan daya saing perusahaan. Pada bisnis kuliner ini, memiliki beberapa kekuatan sebagai berikut:

1. Kombinasi unik yang dimiliki dalam setiap menu yang ditawarkan

2. Packaging produk yang unik dan praktis untuk mempermudah konsumen

3. Kemudahan komunikasi dengan pihak penjual dan pemesana melalui account sosial media

4. Harga jual yang terjangkau

5. Banyaknya event promo yang menarik bagi konsumen

6. Respon para staff kami yang cepat dan tepat

7. Jaminan keamanan dan keselamatan produk dalam pengiriman

\section{Weakness}

Weakness (kelemahan) adalah hal yang menjadi kekurangan oleh perusahaan atau sebuah kondisi yang tidak menguntungkan posisi perusahaan didalam pasar. Pada bisnis kuliner ini, memiliki beberapa kelemahan sebagai berikut:

1. Kelemahan dalam memperkenalkan produk kepada masyarakat

2. Modal yang cenderung rendah

3. Loyalitas konsumen dengan produk sejenis yang dikonsumsi

\section{Opportunity}

Opportunity (kesempatan) adalah faktor yang besar dan utama yang dipertimbangkan dalam membentuk strategi perusahaan. Kesempatan yang dapat digunakan dalam menjalankan bisnis kuliner ini adalah memanfaatkan perubahan teknologi sehingga dapat pengenalan brand yang lebih kepada para konsumen. Dengan terus mengikuti perkembangan teknologi yang ada, 
maka diharapkan dapat mempermudah konsumen dalam berkomunikasi dan bertansaksi terkait dengan produk perusahaan.

\section{Threats}

Threats (ancaman) adalah faktor dari lingkungan eksternal perusahaan yang dapat menganggu profitabilitas dan kesejahteraan perusahaan. Ancaman dalam menjalankan bisnis kuliner ini adalah banyaknya pesaing yang muncul dengan produk yang sejenis dengan varian harga yang jauh lebih murah dengan yang perusahaan tawarkan. Selain itu, ketidak-ketatan dalam hal hak cipta juga mempersulit pebisnis dalam dunia kuliner karena semakin banyak bermunculan pebisnis baru yang meniru produk yang perusahaan tawarkan.

\section{RENCANA KEUANGAN}

Perencanaan keuangan adalah suatu ilmu yang menempatkan kajian tentang keuangan dengan menemoatkan berbagai atribut keuangan secara terkonsep dan sistematis baik secara jangka pendek maupun jangka panjang. Perencanaan keuangan memberikan panduan bagi perubahan dan pertumbuhan yang terjadi didalam perusahaan. Memang salah tujuan dari perencanaan keuangan adalah untuk memberikan arahab atau gambaran terhadap potensi keuangan yang dapat diraih oleh suatu bisnis dan perkembangan perusahaan secara berkelanjutan

\section{Payback Period}

Payback period dapat diartikan sebagai jangja waktu kembalinya investasi yang telah dikeluarkan, melalui keuntungan yang diperoleh dari suatu proyek yang sudah direncanakan. Penetapan payback period maksimum dalam menjalankan suatu bisnis adalah 5 tahun. Payback period dalam bisnis kuliner yang dijalankan ini adalah 2 tahun 9 bulan, dimana jauh lebih cepat dibandingkan periode payback maksimum yang ditetapkan, sehingga usulan investasi ini layak untuk dijalankan.

\section{Net Present Value}

Net Present Value (NPV) merupakan selisih antara pengeluaran yang berupa nilai investasi dan pemasukan yang diharapkan berasal dari proyek tersebut. Nilai Net Present Value diperoleh dengan menghitung selisih antara investasi yang dikeluarkan dengan perkiraan arus kas yang masuk.

Dari hasil perhitungan yang dilakukan sesuai tabel diatas, diketahui bahwa nilai NPV bernilai positif (NPV > 0) sebesar Rp. 1.615.554.130,-. Hal ini menunjukkan bahwa investasi menghasilkan tingkat penghasilan yang melebihi nilai investasi yang dikeluarkan dan menunjukkan bahwa usulan investasi ini harus diterima.

\section{Internal Rate of Return (IRR)}

Internal Rate of Return (IRR) adalah suku bunga yang menyamakan jumlah nilai sekarang dari penerimaan yang diharapkan diterima (present value of future proceed) dengan jumlah nilai sekarang dari pengeluaran untuk investasi.

Tingkat pengembalian (Internal Rate of Return) dari bisnis ini adalah sebesar 19,32\%, dimana nilainya lebih besar dari suku bunga simpanan (deposito) sehingga dapat dikatakan bahwa bisnis ini menguntungkan dan layak untuk dijalankan.

\section{KESIMPULAN}

Berdasarkan analisa dan pembahasan yang telah dijabarkan sebelumnya diatas, maka dapat disimpulkan bahwa bisnis ini layak untuk dijalankan dengan pertimbangan anatara lain, sebagai berikut:

1. Konsep bisnis kuliner yang dibangun bertujuan untuk mempermudah konsumen dalam menikmati makanan yang diinginkan dengan packaging yang mudah dibawa kemana saja dan dapat dinikmati kapanpun diinginkan.

2. Potensi pasar bisnis kuliner ini semakin meningkat, terutama untuk pasar dalam negeri. Hal ini dapat dilihat dengan minat warga Indonesia terhadap makanan dengan citra rasa 
pedas. Kegemaran dan kebiasaan warga Indonesia untuk mengkonsumsi sambel pada saat menikmati makanan merupakan potensi besar untuk menjalankan bisnis ini.

3. Perancangan keuangan menunjukkan bahwa bisnis ini akan memberikan profit bagi para investor dan dari hasil proyeksi keuangan menunjukkan bisnis ini layak untuk direalisasikan.

4. Analisa instrument keuangan yang terdiri dari nilai payback period yang menujukkan angka kurang dari 4 tahun, dimana angka tersebut berarti dibawah dari waktu maksimal yang ditetapkan. Dengan nilai NPV yang positif sebesar Rp. 1.615.554.130,- dan nilai pengembalian internal (IRR) sebesar 19,32\% yang mana lebih tinggi dari suku bunga simanan (deposito) pada umumnya. Analisa instrument keuangan ini menunjukkan bahwa bisnis ini layak untuk diinvestasikan dan dijalankan.

Berdasarkan hasil dari studi kelayakan (feasibility study) yang telah dilakukan melalui analisis yang sudah diperhitungkan dengan baik, dan dengan estimasi penjualan yang mendekati rata-rata penjualan dari usaha sejenis yang sudah berjalan. Maka dapat disimpulkan jika bisnis pengolahan dan penjualan kuliner Sambel Ny. Gunawan ini layak dan dapat dijalankan bisnisnya.

\section{DAFTAR PUSTAKA}

Anggreani D. (2013). Bab 2 Tinjauan Pustaka. Retieved April 18, 2016, from http://repository.widyatama.ac.id/xmlui/bitstream/handle/123456789/2696/Bab\%202.p df? sequence $=7$

Barney, J. B., \& Hertley, W. (2012). Strategic Management and Competitive Advantage. New Jersey: Prentice Hall.

Bones, J. B., \& Hammersley. (2015). Leading Digital Strategy: Driving, Business Growth through Effective E-Commerce. London, UK: Kogan Page.

David, F. R. (1993). Strategic Management, Concept \& Cases 8e. Upper Saddle River, New Jersey: Prentice Hall, Inc.

Dollinger, M. J. (2003). Entrepreneurship Strategies and Resources (3th ed.). US: Pearson Education Inc.

Kementerian Perdagangan Republik Indonesia. (2019). Produk Makanan dan Minuman Makin Diminati. Retrieved September 23, 2019, from Kementerian Perindustrian Republik Indonesia. From https://www.kemendag.go.id/id/search/produk-makanan-danminuman-makin-diminati-indonesia-bukukan-usd-238-juta-di-fine-food-australia-2019-1 .

Kementerian Perindustrian Republik Indonesia. (2017). Industri Makanan dan Minuman Masih Menjadi Andalan. Retrieved November 24, 2017, from Kementerian Perindustrian Republik Indonesia. From https://kemenperin.go.id/artikel/18465/Industri-Makanandan-Minuman-Masih-Jadi-Andalan.

Kementerian Perindustrian Republik Indonesia. (2018). Analisis Perkembangan Perindustrian. Retrieved March 3, 2018, from Kementerian Perindustrian Republik Indonesia. From https://Analisis\%20Perkembangan\%20Industri\%20(Edisi\%20II\%20\%202018).pdf.

Kementerian Perindustrian Republik Indonesia. (2019). Industri Makanan dan Minuman Bakal Tumbuh 9 Persen. Retieved April 20, 2019, from Bisnis Tempo. From https://bisnis.tempo.co/read/1197530/menperin-2019-industri-makanan-minumanbakal-tumbuh-9-persen.

Kotler, P., \& Armstrong, G. (2008). Prinsip-prinsip Pemasaran (Edisi 12). Jakarta: Erlangga. 